\title{
The research on the advantages and countermeasures of the development of private education in China
}

\author{
Tang Tiehan \\ Xijing university, Xi'an, 710123, China
}

\begin{abstract}
Keywords: private education, development advantage, development strategy
\end{abstract}
\begin{abstract}
Private higher school refers to the higher academic education or higher non-academic education institutions that are geared to the needs of society by enterprises and institutions, social groups, other social organizations and individual citizens with non-state financial education funds and according to the standards of higher school promulgated by the country and the local administrative education department. The private education, especially the private college has become an important part of our national education. It provides more higher education opportunities for the masses of the people and play an important role in speeding up China's popularization of higher education. This paper analyzes the current situation of private education in China, especially the advantages, but also pointed out the shortcomings and studied the follow-up development strategies .
\end{abstract}

\section{Introduction}

After nearly 30 years of development, private education of all types from small to large have became the important part of socialist education career. Whether the size of the schools and students in private schools in China or its covered area show a vitality to the private schools disappeared in the $1950 \mathrm{~s}$. The significant achievements and valuable experience has caused extensive concern of the society from all walks of life. It has covered all the national sequence education field from kindergarten to higher education.

\section{Main advantages of private colleges and universities in China}

Compared with public colleges, private colleges and universities still have considerable advantages, mainly in the following areas:

Private colleges and universities can independently determine their own direction of running schools, formulate their own development strategies.

The school orientation is not political orientation, but the academic direction and business direction. That is to say, private colleges can choose suitable type of running (research, teaching, or teaching research university, academic or vocational college) and development mode, and achieve a high degree of academic freedom, formulate their training objectives. As a result of the modern private colleges in our country starting late, only 20 years of history, the government are also mostly limited in the aspect of professional to the orientation of private colleges and universities. But even so, private colleges in our country for their own school-running direction or have their own sovereignty. They are generally not large but less in order to meet more including some of the new mechanism of independent colleges (such as: Guangzhou university institute of fashion technology, college of south China university of technology, automobile, etc.), they made in a subject formed on their own characteristics and advantages. Most of their position is to train applied talents (professional), there are quite a number of private colleges is derived from the higher vocational education (including a large part of the new rise of run by the local undergraduate colleges and universities), strive to maintain advantages of their own in the direction of higher vocational education to a public university and the competitive.

Private colleges can independently determine their own internal management structure, take their own management style, set its own management system.

Private colleges can according to the actual need to set up their own internal management 
structure. Determine the internal management structure of undisturbed, enjoys high autonomy. At the same time, the control of private colleges set up is not the same, each one has its characteristic. Principle and starting point of the construction of internal management mechanism is streamlined. The establishment of institutions will be set up, can be set and not set of institutions to implement functions merge, shouldn't have firmly established institutions is not set up. In general, private colleges management structure to the market and the school daily management work of some new situations and new problems arising from the reaction is rapid. Decision process is clear simple and efficient, and the decision-making cost is low. Management structure can also be made the necessary adjustments with the development of the school at any time, and even to "shuffle" reorganization and integration. Match the management structure, private colleges can decide independently according to the actual school management, develop their own management system.

Look from stimulating investment and domestic demand, private education has attracted a large number of non financial education investment, expand the domestic demand and promote the harmonious development of society.

It must be seen that the local education is in the national important areas to increase investment and stimulating domestic demand, in the current critical moment of against the financial crisis it has special important significance. According to a rough estimate, only bear the degree education of the country's private schools and the kindergartens direct absorption staff of about 3 million people; the traffic, communication, post and telecommunications, information, network, power, construction, building materials, food, food and beverage, retail, processing, paper making, publishing, printing, clothing, financial and other industries driven by it can solve the indirect employees about 4 million people. According to that to create each job assumption needs 50000 Yuan, it increase the investment of 350 billion Yuan for countries. Such as average annual income by 20000 yuan per person, the consumption possibility is increased about 150 billion Yuan. Such investment and consumption to economic development is not only a direct drive, but also has inestimable significance to promote the social harmony and the improvement of national quality.

The rise of private education promote the diversity of education investment in China and the diversification of funding sources.

For 30 years, private education has a diversified investment and financing, including donor partners raise, tuition fees rolling development, education, business investment, overseas financing and listed companies work with schools and so on, changed the lasted for decades of state for education and unified allocation of single mode.

From the development and operation mode, some private schools has from the traditional mode of running a school by the sponsor to promote the cooperation between colleges, as well as the combination of production, chain management, industrial investment, according to the scale, industrialization, collectivization direction development.

Many private schools use of market mechanisms to promote private education career, with education linkage and taking out of the industrial chain, explore distinctive education industry development path. Private schools in Henan province education include: to educated, rolling development model, independent college education group, group investment model and investment managerial mode, etc. Some education group in the province has including elementary school, middle school, high school 1 and Henan agricultural university Huayu college 5 schools, the number of students is up to more than 20000.

Private education in our country has the collectivization development phenomenon. A batch of domestic and foreign well-known the education emergence group has formed. Most of the group, not only have different levels of private schools, but also involved in business, real estate, real estate and investment in the field of second and third industry related or business activities (with the United States education industry group is mainly engaged in "education services" business different), some also to overseas investment in running schools, the strong comprehensive is strength. 


\section{Private education's contribution to the society}

In fact, just solve the problem of the education fair and balanced development of our country, the private schools have helped the government a lot. Include:

Firstly, the private education directly to vulnerable groups, including a large number of migrant children, impoverished students, special students, rural laborer, laid-off, transferred and unemployed personnel, to provide them with basic education and training, improve the basic quality and ability, to increase the chances of employment and reemployment.

Secondly, the vigorously develop of private education has increased the amount of education funds in our country, reduce the burden of the public finances, is conducive for all levels of government to development public schools having more financial resources and ability, further promote the education fair.

Thirdly, private schools provide diversity of choice, made a number of objects gave away the chance to study in the public schools, thus make room for the public school degree and save the cost of running, let more objects to enjoy public resources, promote social harmony and stability.

\section{The existing problems in the development of private education in China}

The lag in policy making, laws and regulations system is incomplete.

"Private education promotion law" has been issued for many years, and its "implementation regulations" and so on is lack of some important file content, or some important terms exist interoperability is not strong, which is difficult to implement; The relevant laws and policy system elbow each other; A number of supporting policies should be quite cannot appear so far; For the temporary emergency and easy lack of certain provisions of the height of commanding the whole situation and long-term point of view.

\section{rights.}

The properties institutions in private schools are fuzzy, which leads to the unclear property

The law explicitly stipulated: "private education belongs to public welfare undertakings, career is a component part of socialist education". However, private schools in the civil affairs department registration, according to the relevant government laws and regulations has been defined as "a people-run non-enterprise unit", it is a new concept put forward beyond the "general principles of the civil law". In spite of the concept of "a people-run non-enterprise unit", but in private schools did not formulate corresponding policies about the tax, teachers' welfare, social insurance, and other important issues, on the contrary only according to the standards of enterprise, and did not be treat as by "business".

\section{There is no reasonable solution for a reasonable return.}

Allow a reasonable return is an important and special provisions that the "private education promotion law" according to the present stage that in our country there are very few people donated school's basic national conditions, to attract private and social resources to promote education development. However, the private education promotion law is lack of operability implementation regulations for non-governmental schools get reasonable return the provisions; Relevant administrative departments and the public welfare of private education and private education promotion law "about the investor" can make a reasonable return from running in the balance "the provisions of the opposition to understand, cannot appear the preferential measures to form a complete set of legal regulations, seriously affected the enthusiasm of private schools by the sponsor, and standardize the management of private schools.

The legal support and incentives have not fully implemented.

"Private education promotion law" and the "regulations on the implementation of the provisions, including setting up special funds, funds appropriated funding, tax incentives, credit support, responsible for compulsory education funds and land use and construction of preferential and so on, incentive measures, the relevant government departments and many areas have been unable to fully implemented. 


\section{Private education is not included in the national economic and social development plan in accordance with the law.}

Private education law has been identified as "part of the socialist education", but has not yet been incorporated into the national economic and social development planning at all levels in accordance with the law, until into public budget. Relevant government departments even has mistake idea that the private schools is a non-state financial funds, and therefore cannot enjoy financing and reward. This defines with the international understanding of private education and the advanced concepts.

\section{Development of China's private education}

Firstly, expand the connotation of private education.

For a long time, because of narrow understanding to private schools' "male" and "private" problems, it hard to make a decision with private schools attribute and reward, taxation and public finance support and teachers' identity and benefits such as problems. It is necessary according to the definition of international organizations, in addition to the "use of non-state financial funds" education as in the past to define standards of private schools in our country, the development for all by non-governmental or non public institutions responsible for the management of schools and other institutions of education (including Chinese-foreign cooperation in running schools, etc.), also belong to the category of private education. This is conducive to further to form the whole society in our country held in various forms to actively participate in education.

Secondly, whole the public education and the development of private education, practical and creating an environment of fair competition between schools and multi-running pattern.

In accordance with the principle of "five independent", for public schools to participate in the host charter schools as a real specification.

According to the general requirements of building a socialist market economy system, deepen and speed up our country's education investment system, management system, reform of school-running system, effectively absorb more social resources into the field of education. On the premise of clear property rights, encourage to completely private and public people to help, business to manage, by civilian, business restructuring, and Chinese and foreign cooperation, and other forms of running a school, one thousand ways to form the great pattern of diversified system of running a school.

Thirdly, promote private schools specification in running in accordance with the law.

Take strong and effective measures to promote the private schools to implement school legal person property rights; Truly establish corporate governance structure in private schools, set up in accordance with the law by stakeholders representatives to attend face-to-face, reasonable structure of the council) (or the board of directors and board of supervisors, exercise decision-making rights according to law, to ensure democratic decision-making, scientific decision-making; The implementation of the staff and social related party to participate in democratic management, public supervision and rights; Construct high quality school leadership; Consciously implement national laws and policies, laws and regulations, fully implement the national education policy, adhere to the socialist direction of running education and public welfare principle, safeguard the rights and interests of teachers and students, respect the rule of law of education and market, and pay attention to the education quality, improve the management level, efforts to build modern school system and the construction of harmonious campus, to ensure the road of the safe and stable, science, the connotation, sustainable development.

\section{Conclusion}

With the constant improvement of relevant legal systems of our country and the transformation of the general public ideology concept, combined with private colleges own complement each other, our private universities might be like many countries in Europe and the United States as a first-class university one day. 


\section{References}

[1] He Xiuyan. Comparative advantage and the development of China's non-government college. Pioneer China education network.

[2] Mao Jianqing. Internal factors which restrict the development of the private colleges in our country analysis and suggestion. Pioneer China education network.

[3] Zhang Shengjun, Zhang Letian. Private higher education policy in China since 1978 for the construction of history, achievements and problems. Pioneer China education network.

[4] China's ministry of education. The national medium and long-term education reform and development plan outline (2010-2020), 2010.7.29. 